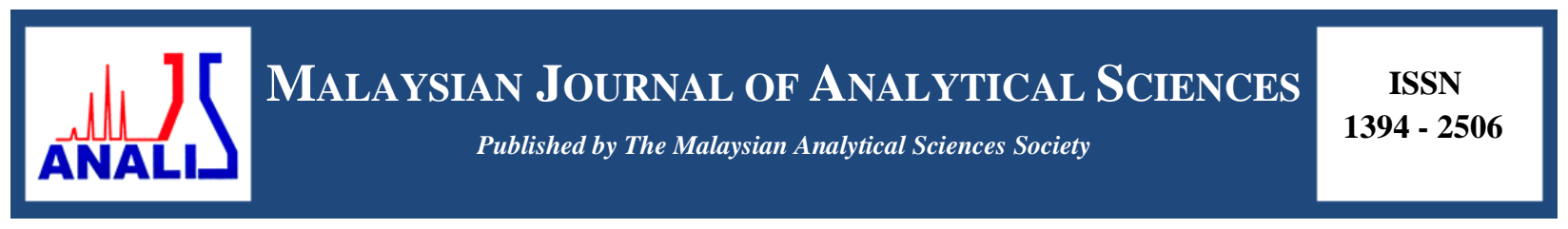

\title{
ELECTROCHEMICAL PROPERTIES OF POLYMER ELECTROLYTES TREATED WITH 6PPD ON 30\% POLY(METHYL METHACRYLATE) GRAFTED NATURAL RUBBER
}

\author{
(Sifat Elektrokimia Elektrolit Polimer 30\% Poli(Metil Metakrilat) Cangkutan Getah Asli \\ Terawat Dengan 6PPD)
}

\author{
Ahmad Fairoz Aziz ${ }^{1}$, Khuzaimah Nazir ${ }^{1}$. Siti Fadzilah Ayub ${ }^{1}$, Nurul Ilham Adam ${ }^{2}$, Muhd Zu Azhan Yahya ${ }^{3}$, \\ Ab Malik Marwan Ali ${ }^{1,4} *$ \\ ${ }^{1}$ Faculty of Applied Sciences, \\ Universiti Teknologi MARA, 40450 Shah Alam, Malaysia \\ ${ }^{2}$ Faculty of Applied Sciences, \\ Universiti Teknologi MARA, 35400 Tapah Road, Perak, Malaysia \\ ${ }^{3}$ Faculty of Defence Science and Technology, \\ Universiti Pertahanan Nasional Malaysia, 57000 Kuala Lumpur, Malaysia \\ ${ }^{4}$ Institute of Science, \\ Universiti Teknologi MARA, 40450 Shah Alam, Selangor, Malaysia \\ *Corresponding author: ammali@salam.uitm.edu.my
}

Received: 4 December 2016; Accepted: 1 December 2017

\begin{abstract}
$30 \%$ poly(methyl methacrylate) grafted natural rubber was treated with N-(1,3-dimethylbutyl)-N'-phenyl-p-phenylenediamine (6PPD) additive (TMG30) to retard its degradation before further used as electrolytes. The polymer electrolytes containing MG30-6PPD-LiTF were prepared by solution cast technique. X-ray diffraction studies show the electrolytes with the highest salt content are amorphous in nature. The TMG30-salt complexes were confirmed by using Fourier transformation infrared analysis. The highest ionic conductivity of the TMG30 polymer electrolytes containing $40 \mathrm{wt} . \% \mathrm{LiTF}$ was found to be $1.5 \times 10^{-2} \mathrm{~S} / \mathrm{cm}$ at room temperature. Transference number studies show that the sample with highest ionic conductivity exhibits the charge transport species in this TMG30 polymer electrolyte film is predominantly due to ions.
\end{abstract}

Keywords: methyl-grafted natural rubber, n-(1,3-dimethylbutyl)-n'-phenyl-p-phenylenediamine, polymer electrolytes

\begin{abstract}
Abstrak
$30 \%$ poli(metil metakrilat) cangkutan getah asli telah terawat dengan bahan tambah N-(1,3-dimetilbutil)-N'-fenil-pfenilindiamine (6PPD) (TMG) untuk melambatkan kemerosotan sebelum digunakan sebagai elektrolit. Elektrolit polimer yang mengandungi MG30-6PPD-LiTf telah disediakan melalui teknik pengacuan larutan. Kajian pembelauan sinar-X menunjukkan elektrolit dengan kandungan garam tertinggi berada dalam keadaan amorfus. Pengkompleksan TMG30-garam telah disahkan dengan menggunakan analisis spektroskopi inframerah transformasi Fourier. Elektrolit polimer TMG30 mengandungi 40 wt.\% LiTF didapati menghasilkan kekonduksian ionik tertinggi pada $1.5 \times 10^{-2} \mathrm{~S} / \mathrm{cm}$ untuk di suhu bilik. Kajian nombor angkutan terhadap sampel filem elektrolit polimer TMG30 yang mempunyai kekonduksian ionik tertinggi menunjukkan pengangkutan cas dalam sampel tersebut adalah disebabkan oleh pergerakan ion.
\end{abstract}

Kata kunci: cangkutan metil-getah asli, n-(1,3-dimetilbutil)-n'-fenil-p-fenilindiamin, elektrolit polimer 


\section{Introduction}

Researches on polymer electrolytes (PEs) have been progressively done in recent years. This type of electrolytes offer high ionic conductivity and can provide good electrode-electrolyte contact which make it suitable to be implemented in electrochemical devices. Modified natural rubber (MNR) has a low glass transition temperature $\left(\mathrm{T}_{\mathrm{g}}\right)$, soft elastomer characteristics at room temperature, good elasticity and possess adhesive properties. Such characteristics fitted MNR to be used as PEs for further development. Since its ability to form PEs, various types of MNR based PEs have been produced by various techniques and additives. Ichino et al. [1] become the pioneer of using MNR electrolytes in the year 1993. In their studies they tried to overcome low mechanical stability of plasticized PEs. Their idea was utilizing the mechanically strong butadiene rubber to support polystyrene polymer electrolytes and declared the finding as dual-phase polymer electrolyte. Until today research has been geared to enhance the electrolytes properties of MNR particularly to obtain high ionic conductivity at room temperature with better mechanical properties. Various MNR has been used such as by using epoxidized natural rubber (ENR-25 and ENR-50) [2-5] and methyl grafted natural rubber (MG49 and MG30) [6-10] as a polymer host to produce PEs. The introduction of metal oxide inorganic filler such as $\mathrm{TiO}_{2}, \mathrm{SiO}_{2}$ and $\mathrm{Al}_{2} \mathrm{O}_{3}$ also was reported successfully enhanced the mechanical properties and improve ionic conductivity at room temperature [11-13].

Studied also goes to use the high dielectric constant plasticizer as additive like ethylene carbonate and propylene carbonate and showed an improvement in ionic conductivity $[14,15]$. However, all these type of electrolytes degrade with age. Report on retarding degradation problems based on MNR PEs is yet unpublished. The unsaturated $\mathrm{C}=\mathrm{C}$ bond in natural rubber polymer backbone is considerably weak and easily breakdown with relatively low energy. The degradation process is more prone when MNR is being exposed to certain conditions such as ultra violet rays, high temperature and mechanical shear.

Nevertheless, studies has been done to retard the degradation of MNR by compromising N-(1,3-dimethylbutyl)-N'phenyl-p-phenylenediamine (6PPD). It is a natural rubber antioxidant that was proven works onto rubber derivatives to retard the degradation $[16,17]$. Our previous work have reported that by using $0.5 \mathrm{wt} . \%$ of 6PPD was reduce the $30 \%$ poly (methyl methacrylate) grafted natural rubber (MG30) degradation [18]. So, in this work, the same amount 6PPD additive will be used in order to enhance the ionic conductivity of the polymer electrolytes based on MNR in which the MG30 was treated with 0.5 wt.\% 6PPD to form TMG30. Polymer electrolytes consisting TMG30 and lithium trifluoromethanesulfonate (LiTF) system was prepared. Several methods were employed to distinguish the physical and electrical properties of the prepared samples including X-ray diffraction (XRD), Fourier transform spectroscopy (FTIR), ac impedance spectroscopy (EIS) and transference number.

\section{Materials and Methods}

MG30 was obtained from Rubber Research Institute of Malaysia (RRIM) and lithium trifluoromethanesulfonate (LiTF) was obtained from Sigma Aldrich. N-(1,3-dimethylbutyl)-N'- phenyl-p-phenylenediamine (6PPD) antioxidant pallet was supplied by Centre West Industrial Supplies. All the materials were used without further purification. The samples comprising MG30 as host polymer, LiTF as doping salt, and 6PPD as antioxidant were prepared by the solution cast technique. MG30 was minced into smaller pieces and 0.5 wt.\% 6PPD pellet was ground into powder before being dissolved in tetrahydrofuran (THF) solution (Mallinckrodt Baker Inc., USA) separately. LiTF solution was prepared separately in tetrahydrofuran solution and stirred for about 12 hours. MG306PPD-LiTF solution then mixed together and stirred for 24 hours at room temperature to form homogenous electrolytes solution. The electrolytes solution then poured into caped petri dish and left to slowly evaporate in fume hood. Electrolytes thin films were obtained then continue to dry in drying cabinet to remove all residual solvent before further used.

X-ray diffraction (XRD) studies were recorded at room temperature by using Philips X'Pert PRO diffractometer in the range of $2 \theta$ between $10^{\circ}$ and $80^{\circ}$. Infrared studies were performed by using FTIR Perkin Elmer Spectrum 400 in wave region of 4000 to $500 \mathrm{~cm}^{-1}$. Electrical measurements were done on a computer-controlled HIOKI 3532-50 LCR hi-tester in the frequency ranging from $100 \mathrm{~Hz}$ to $1 \mathrm{MHz}$ at room temperature with stainless steel blocking electrode. Transference number $\left(t_{n}\right)$ were tested on WonATech WBCS 3000 automatic battery cycler and evaluated by using Wagner's polarization technique. A constant dc potential $(10 \mathrm{mV})$ was applied across the samples through 
two symmetrical blocking electrode. The current was monitored as a function of time until it reached a constant value.

\section{Results and Discussion}

Figure 1 shows XRD plot of TMG30 polymer electrolyte with various concentration from $10^{\circ}$ to $80^{\circ}$. A peak has spotted at around $18^{\circ}$ of all samples. The peak intensities are decreasing and broader with salt concentration suggested that the samples with more salt concentration are more amorphous in nature. This finding was contradict with MG30:LiTF polymer electrolytes system without 6PPD found by other researcher suggested that 6PPD had involved in the formation of amorphous nature in TMG30:LiTF [8]. The behaviour of 6PPD in TMG30 mimics the plasticizer-like behaviour in polymer electrolytes. The amorphous nature of polymer electrolytes has been reported increased upon the introduction of plasticizer and increase the ionic conductivity. Amorphous nature is very essential in polymer electrolytes for ion conduction mechanism that allows the ion movement easier by providing larger ionic path that lowering ion migration activation energy. Polymer electrolyte consist of $45 \mathrm{wt}$. \% of LiTF are expected to have the highest ionic conductivity considering of it most amorphous nature state.

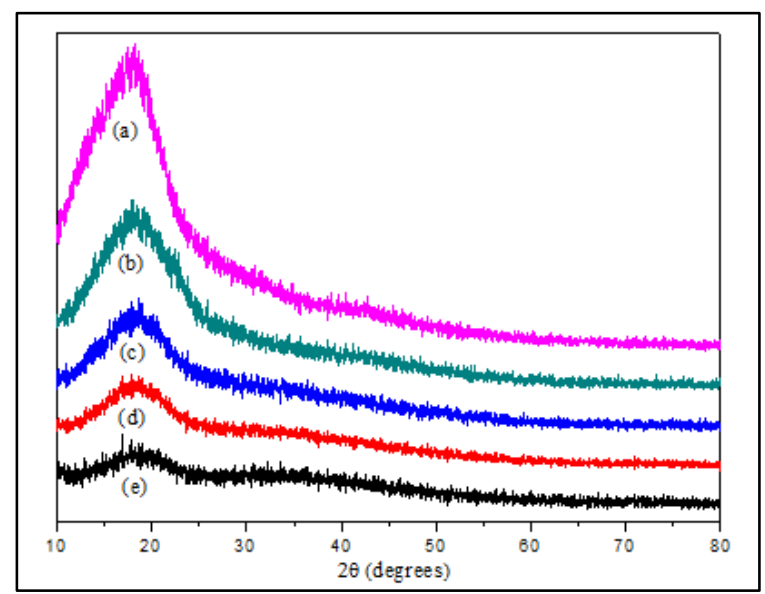

Figure 1. XRD pattern of TMG30 polymer electrolytes ranging between $10^{\circ}$ and $80^{\circ}$ with function of LiTF wt.\% (a) 0 , (b) 10, (c) 30, (d) 40 and (e) 45

FTIR spectroscopy was done to establish the interactions between the polymer and salt which identify any changes in the electronic levels of the atoms. In our previous studies it was observed that the oxygen atoms with lone pair of electron $(\mathrm{C}=\mathrm{O})$ from poly(methyl methacrylate) (PMMA) in MG30 play a vital role as electron donor in the polymer host. A dative bond between $\mathrm{C}=\mathrm{O}$ and $\mathrm{Li}^{+}$from the salt will form polymer-salt complex [19]. In MG30 FTIR spectra, the $\mathrm{C}=\mathrm{O}$ symmetrical stretching frequency gives rise to an intense and sharp peak at $1729 \mathrm{~cm}^{-1}$. The vibrational peaks at $1193 \mathrm{~cm}^{-1}, 1149 \mathrm{~cm}^{-1}$, and $748 \mathrm{~cm}^{-1}$ are assigned to $\mathrm{CH}_{2}$ in-plane bending mode of polyisoprene, $\mathrm{CH}_{2}$ twisting mode of PMMA and $\mathrm{CH}_{2}$ rocking mode of PMMA, respectively. Other MG30 peaks have presented and identified as observed in literature studies $[15,19,20]$. No significant peaks of 6PPD additive spotted throughout the FTIR spectra. This is maybe due to its small amounts of concentration at $0.5 \mathrm{wt} . \%$.

Figure 2 depicts FTIR spectra of TMG30-LiTF complexes in the region between $1600 \mathrm{~cm}^{-1}$ and $1800 \mathrm{~cm}^{-1}$. A sharp peak at $1729 \mathrm{~cm}^{-1}$ belong to $\mathrm{C}=\mathrm{O}$ symmetrical stretching of PMMA were found to be shifted to lower wavenumber for sample TMG30-salt complexes. The $\mathrm{C}=\mathrm{O}$ carbonyl stretching mode shifted to the lower wavenumber and reduced in intensity confirmed the polymer salt interactions take place and is in agreement with a previous report [14]. The peak at $1648 \mathrm{~cm}^{-1}$ become more obvious with salt incorporation suggested that LiTF is contributed to the peak growth. This peak is overshadowed the peak of $\mathrm{C}=\mathrm{C}$ symmetric stretching of polyisoprene from MG30 at 1664 $\mathrm{cm}^{-1}[19]$. 


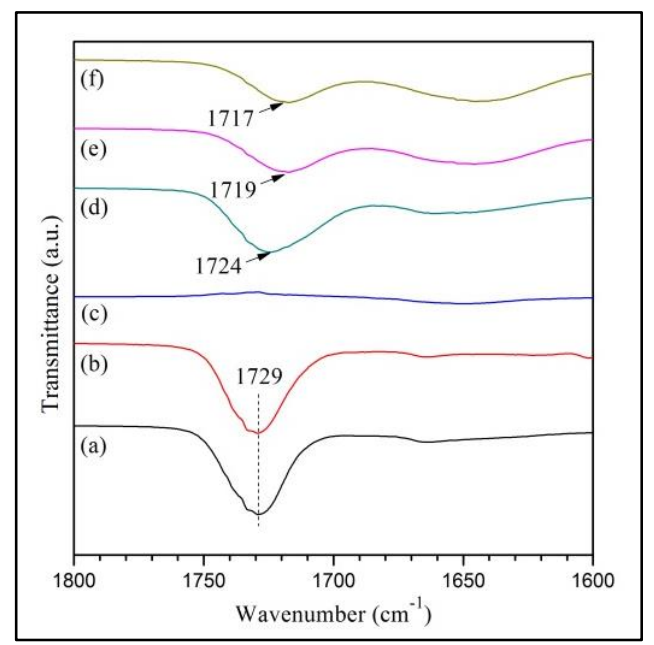

Figure 2. FTIR spectra region from $1600 \mathrm{~cm}-1$ to $1800 \mathrm{~cm}-1$ of (a) MG30, (b) TMG30, (c)LiT, (d) TMG30 + 10 wt.\% LiTF, (e) TMG30 + 30 wt. \% LiTF, (f) TMG30 + 40 wt.\% LiTF

Several new peaks have been observed upon incorporating LiTF in the TMG30 at $1175 \mathrm{~cm}^{-1}, 1031 \mathrm{~cm}^{-1}$ and 765 $\mathrm{cm}^{-1}$. These peaks were originally shifted from $1186 \mathrm{~cm}^{-1}, 1045 \mathrm{~cm}^{-1}$ and $776 \mathrm{~cm}^{-1}$ which belong to antisymmetric $\mathrm{CF}_{3}$ stretching, symmetric $\mathrm{SO}_{3}$ stretching and symmetric $\mathrm{CF}_{3}$ deformation mode of LiTF. The band $1193 \mathrm{~cm}^{-1}$ of $\mathrm{CH}_{2}$ in-plane bending mode of polyisoprene is shifted and totally disappeared at $40 \mathrm{wt} . \%$ salt incorporation. The peak $1149 \mathrm{~cm}^{-1}$ of $\mathrm{CH}_{2}$ twisting mode of PMMA shifted to higher wavenumber and overlapped under the peak 1175 $\mathrm{cm}^{-1}$ as shown in Figure 3. The shifted peak of symmetric $\mathrm{SO}_{3}$ stretching of LiTF in the TMG30 is shown in Figure 4. $\mathrm{CH}_{2}$ rocking mode of PMMA at $748 \mathrm{~cm}^{-1}$ has been observed in all samples incorporating LiTF as shown in Figure 5. The shifting antisymmetric $\mathrm{CF}_{3}$ stretching, symmetric $\mathrm{SO}_{3}$ stretching and symmetric $\mathrm{CF}_{3}$ deformation mode of LiTF upon the addition of LiTF in the TMG30 signify that $\mathrm{Li}^{+}$ions have been coordinated in TMG30.

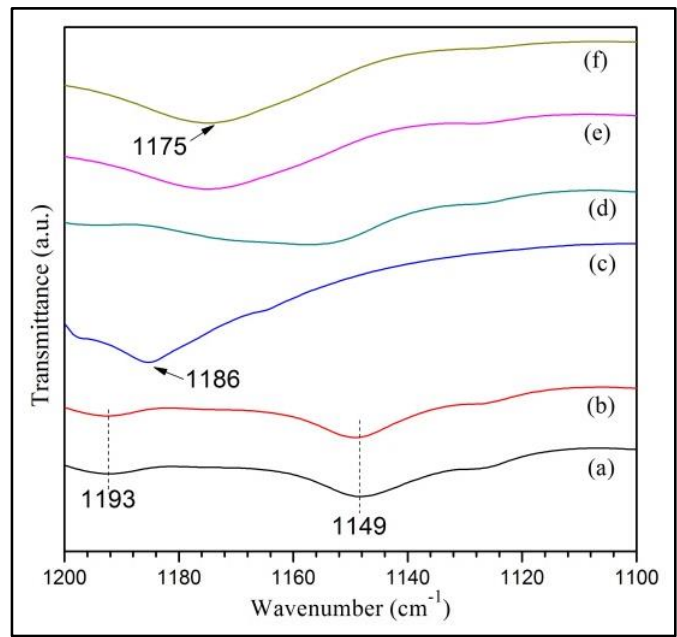

Figure 3. FTIR spectra region from $1100 \mathrm{~cm}^{-1}$ to $1200 \mathrm{~cm}^{-1}$ of (a) MG30, (b) TMG30, (c)LiTF, (d) TMG30 + 10 wt.\% LiTF, (e) TMG30 + 30 wt.\% LiTF, (f) TMG30 + 40wt.\% LiTF 


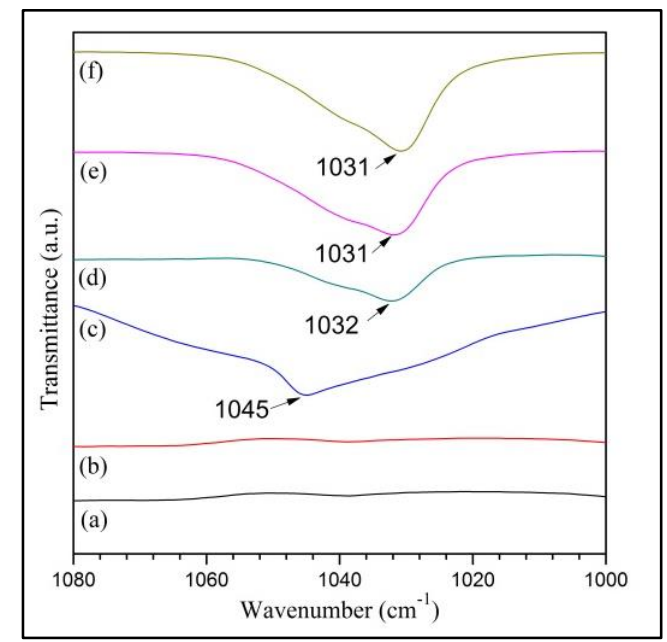

Figure 4. FTIR spectra region from $1000 \mathrm{~cm}^{-1}$ to $1080 \mathrm{~cm}^{-1}$ of (a) MG30, (b) TMG30, (c)LiTF, (d) TMG30 + 10 wt.\% LiTF, (e) TMG30 + $30 \mathrm{wt} . \% \mathrm{LiTF}$, (f) TMG30 + $40 \mathrm{wt} . \% \mathrm{~L}$

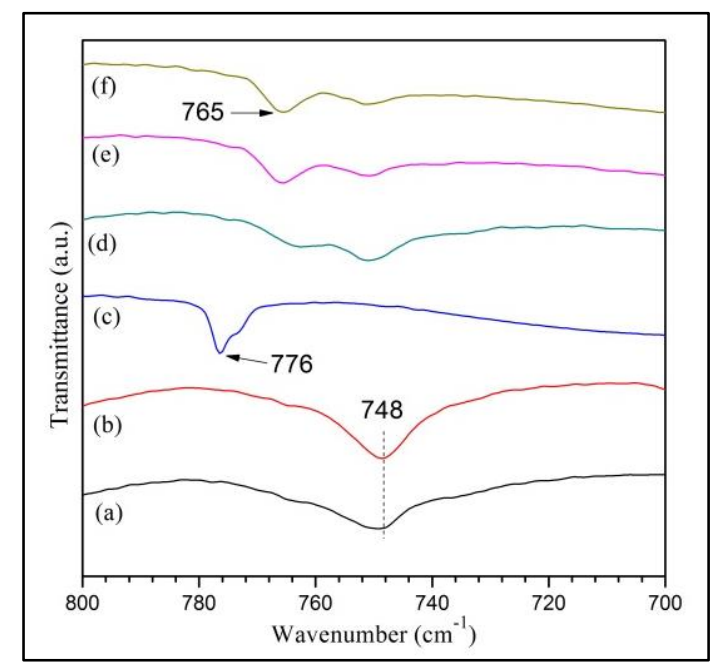

Figure 5. FTIR spectra region from $700 \mathrm{~cm}^{-1}$ to $800 \mathrm{~cm}^{-1}$ of (a) MG30, (b) TMG30, (c) LiTF, (d) TMG30 + 10 wt\%LiTF, (e) TMG30+30wt\% LiTF, (f) TMG30 + 40 wt.\% LiTF

Figure 6 depicts the ionic conductivity of TMG30 in function of LiTF concentration. The ionic conductivity is increasing with the salt concentration. The ionic conductivity of the TMG30-salt complexes above $40 \mathrm{wt} . \%$ of LiTF was not measured due to undesired physical characteristic. This is in agreement with the XRD result in Figure 1 which shows that sample with higher salt concentration is tendency to have more amorphous state. This also explained the reason of the sample having higher ionic conductivity at higher salt concentration which can classify that TMG30-LiTF polymer complex have plasticized-like behaviour and unlike MG30-LiTF polymer salt complexes as reported in literatures [6,21]. From Figure 6, it was observed the TMG30 with 40 wt.\% of LiTF obtained an optimum ionic conductivity with the value of $1.5 \times 10^{-2} \mathrm{~S} / \mathrm{cm}$ at room temperature. 


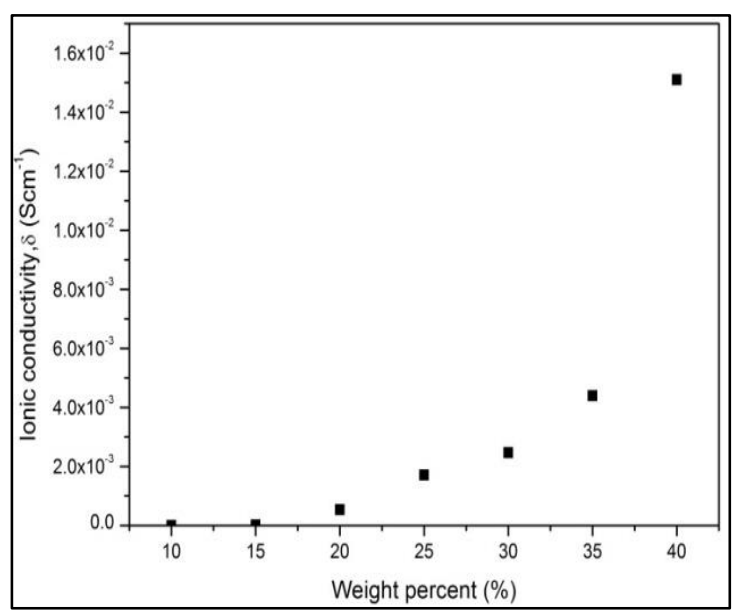

Figure 6. Ionic conductivity of TMG30 polymer electrolytes in function of LiTF concentration at $303 \mathrm{~K}$

Figure 7 shows the current polarization versus time to evaluate the transference number $\left(t_{n}\right)$. The value of $t_{n}$ was calculated using the equation 1.

$$
\mathrm{t}_{\mathrm{n}}=\left(\mathrm{I}_{\mathrm{i}}-\mathrm{I}_{\mathrm{ss}} \mathrm{s}\right) / \mathrm{I}_{\mathrm{i}}
$$

where $I_{i}$ is the initial current and $I_{s s}$ is the steady state current. The time variation of the current through the sample corresponds to the polarization at electrode/electrolyte interface. TMG30 with $40 \mathrm{wt} . \%$ LiTF was selected for the test is due to its highest ionic conductivity. The value of the ionic $t_{n}$ is found to be 0.989 suggested that the ions is predominantly act as charge transport in TMG30 polymer electrolytes.

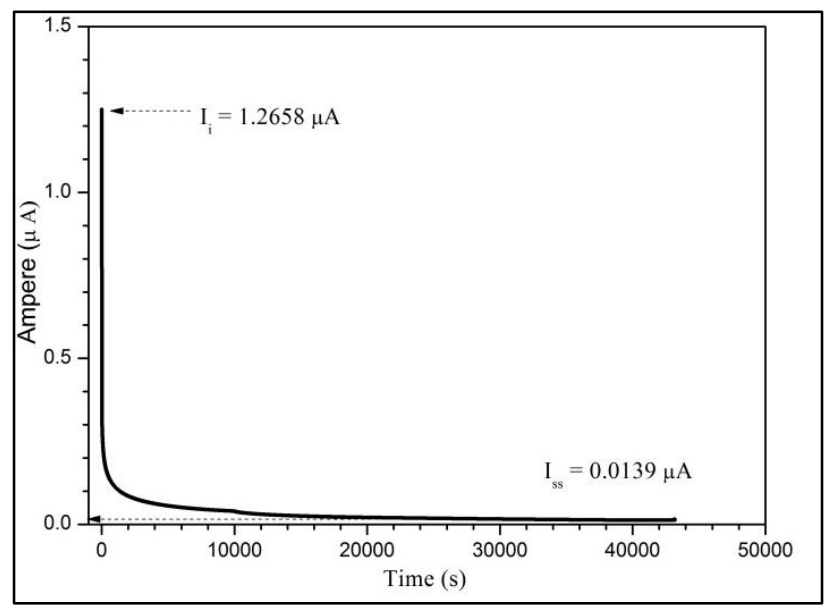

Figure 7. Transference number of TMG30 + $40 \mathrm{wt} . \% \mathrm{LiTF}$

\section{Conclusion}

FTIR studies confirmed TMG30-LiTF complexes occurred. 6PPD additive brings TMG30 polymer electrolytes to new dimension of polymer electrolytes by providing plasticized-like behaviour in physical and electrical properties. The highest ionic conductivity of TMG30 is obtain at $1.5 \times 10^{-2} \mathrm{~S} / \mathrm{cm}$ for sample with $40 \mathrm{wt} \%$ of LiTF. Transference number confirmed the TMG30 electrolyte is predominately by ion conduction. 


\section{Acknowledgement}

The authors wish to thank Universiti Teknologi MARA (UiTM) Shah Alam, Research Management Institute (RMI) UiTM and Ministry of Higher Education Malaysia (MOHE) for the financial support (ERGS/1/2013/STG02/UITM/02/01).

\section{References}

1. Ichino, T. and Matsumoto, M. (1993). New solid polymer electrolytes prepared from styrene-butadiene copolymer lattices. Journal of Polymer Science Part A: Polymer Chemistry, 31: 589-591.

2. Idris, R., Glasse, M. D., Latham, R. J., Linford, R. G. and Schlindwein, W. S. (2001). Polymer electrolytes based on modified natural rubber for used in rechargeable lithium batteries. Journal of Power Sources, 94: 206-211.

3. Latif, F., Aziz, M., Katun, N., Ali, A. M. M. and Yahya, M. Z. A. (2006). The role and impact of rubber in poly(methyl methacrylate)/lithium triflate electrolyte. Journal of Power Sources, 159: 1401-1404.

4. Mohamed, S. N., Johari, N. A., Ali, A. M. M., Harun, M. K. and Yahya, M. Z. A. (2008). Electrochemical studies on epoxidised natural rubber-based. Journal of Power Sources, 183: 351-354.

5. Nazir, K., Ayub, S. F., Aziz, A. F., Zakaria, R., Yahya, M. Z. A. and Ali, A. M. M. (2015). Conductivity and thermal behaviour of epoxidized-30\% poly (methyl methacrylate)-grafted natural rubber-lithium triflate based solid polymer electrolytes, Advanced Materials Research, 1107: 175-180.

6. Ali, A. M. M., Subban, R. H. Y., Bahron, H., Yahya, M. Z. A. and Kamisan, A. S. (2013). Investigation on modified natural rubber gel polymer electrolytes for lithium polymer battery. Journal of Power Sources, 244: 636-640.

7. Kamisan, A. S., Kudin, T. I. T., Ali, A. M. M. and Yahya, M. Z. A. (2011). Electrical and physical studies on 49\% methyl-grafted natural rubber-based composite polymer gel electrolytes. Electrochimica Acta, 57: 207211.

8. Yap, K. S., Teo, L. P., Sim, L. N., Majid, S. R. and Arof, A. K. (2012). Investigation on dielectric relaxation of PMMA-grafted natural rubber incorporated with $\mathrm{LiCF}_{3} \mathrm{SO}_{3}$. Physica B: Condensed Matter, 407: 2421-2428.

9. Nazir, K., Ayub, S. F., Aziz, A. F., Ali, A. M. M. and Yahya, M. Z. A. (2014). Preparation and characterization of epoxidized-30\% poly(methyl methacrylate)-grafted natural rubber polymer electrolyte, Journal of Nano Research, 28: 163-170.

10. Aziz, A. F., Nazir, K., Ayub, S. F., Zakaria, R., Yahya, M. Z. A. and Ali, A. M. M. (2015). Impedance behavior of treated methyl-grafted natural rubber polymer electrolytes. Advanced Materials Research, 1107: $217-222$.

11. Tian Khoon, L., Hassan, N. H., Rahman, M. Y. A., Vedarajan, R., Matsumi, N. and Ahmad, A., (2015). Onepot synthesis nano-hybrid $\mathrm{ZrO}_{2}-\mathrm{TiO}_{2}$ fillers in $49 \%$ poly(methyl methacrylate) grafted natural rubber (MG49) based nano-composite polymer electrolyte for lithium ion battery application. Solid State Ionics, 276: 72-79.

12. Chew, K. W. and Tan, K. W. (2011). The effects of ceramic fillers on PMMA-based polymer electrolyte salted with lithium triflate, $\mathrm{LiCF}_{3} \mathrm{SO}_{3}$. International Journal of Electrochemical Science, 6: 5792-5801.

13. Kim, S. H., Choi, K. H., Cho, S. J., Kil, E. H. and Lee, S. Y. (2013). Mechanically compliant and lithium dendrite growth-suppressing composite polymer electrolytes for flexible lithium-ion batteries. Journal of Materials Chemistry A, 1: 4949-4955.

14. Ali, A. M. M., Yahya, M. Z. A., Bahron, H. and Subban, R. H. Y. (2006). Electrochemical studies on polymer electrolytes based on poly(methyl methacrylate)-grafted natural rubber for lithium polymer battery. Ionics (Kiel), 12: 303-307.

15. Kumutha, K., Alias, Y. and Said, R. (2005). FTIR and thermal studies of modified natural rubber based polymer electrolytes. Ionics (Kiel), 11: 472-476.

16. Cibulková, Z., Šimon, P., Lehocký, P. and Balko, J. (2005). Antioxidant activity of 6PPD derivatives in polyisoprene matrix studied by non-isothermal DSC measurements, Journal of Thermal Analysis and Calorimetry, 80: 357-361.

17. Breza, M., Kortišová, I. and Cibulková, Z. (2006). DFT study of the reaction sites of N,N-substituted Pphenylenediamine antioxidants. Polymer Degradation and Stability, 91: 2848-2852.

18. Aziz, A. F. and Ali, A. M. M. (2012). Thermal oxidation studies on methyl grafted natural rubber polymer electrolytes with paraphenylene diamine additive, 2012 IEEE Colloquium Humanity Science \& Engineering: pp. 719-723. 
19. Kumutha, K. and Alias, Y. (2006). FTIR spectra of plasticized grafted natural rubber- $\mathrm{LiCF}_{3} \mathrm{SO}_{3}$ electrolytes. Spectrochimica Acta Part A: Molecular and Biomolecular Spectroscopy, 64: 442-447.

20. Ali, A. M. M., Subban, R. H. Y., Bahron, H., Winie, T., Latif, F. and Yahya, M. Z. A. (2008). Grafted natural rubber-based polymer electrolytes: ATR-FTIR and conductivity studies. Ionics (Kiel), 14: 491-500.

21. Ali, A. M. M., Yahya, M. Z. A., Bahron, H., Subban, R. H. Y., Harun, M. K. and Atan, I. (2007). Impedance studies on plasticized PMMA-LiX $\left[\mathrm{X}: \mathrm{CF}_{3} \mathrm{SO}_{3}-, \mathrm{N}\left(\mathrm{CF}_{3} \mathrm{SO}_{2}\right)_{2}-\right.$ ] polymer electrolytes. Materials Letters, 61: 2026-2029. 